\title{
The List of Aristotelian Types of Motion and Its Extension in De duabus in Christo voluntatibus of John Damascene
}

\author{
Tauri Tölpt \\ PhD candidate, University of Tartu, Faculty of Theology, Tartu, Estonia \\ Tauriitsius@gmail.com
}

\begin{abstract}
John Damascene's use of philosophical logic in his theological treatises has remained a somewhat unclear subject. We know that John compiled purely logical and philosophical works, such as the Institutio Elementaris and the Dialectica. But it is not clear how much, if at all, John's purely philosophical projects contributed to his later theological work. In order to illuminate the issue, I shall take under investigation the Damascene's implementation of the Aristotelian types of motion that are clearly found both in John's philosophic and in his theological works. One of his theological works in which the Aristotelian types of motion are used in tandem with the intelligible motion is the De duabus in Christo voluntatibus. Taking this Christological work as a starting point, this article aims to shed light on the potential sources behind the Damascene's use of the different types of motion and the significance thereof for his arguments against Monothelitism and Monoenergism.
\end{abstract}

\section{Keywords}

Aristotle - motion - John Damascene - Christian philosophy - Monothelitism Monoenergism 


\section{$1 \quad$ Introduction}

The question of how exactly John Damascene implements philosophical logic, especially of an Aristotelian kind, in his theological argumentation has been a matter of intense speculation for some time now. From one side, we see that John put forth the effort to compile works of philosophical kind, such as the Institutio Elementaris (IE) and the Dialectica (Dial.), the latter based on Aristotle's Categories and on the commentary tradition of Porphyry. ${ }^{1}$ If we would like, on the other hand, to imagine John Damascene as a man who engaged with pagan philosophical works or the commentary tradition, then our enthusiasm would be quashed quite rapidly. M. Roueché's thorough studies, which in general are held to be valid up to the present day, show that John and his philosophic works were probably connected neither with any of the works of Aristotle, nor with any of the later commentaries of the Alexandrian School. Instead, John probably used logical handbooks or compendia that were essentially Christianized summaries of basic logical definitions and concepts with a strong Aristotelian background. ${ }^{2}$

It is also little understood to what extent John extends and applies the concepts in his philosophical works, especially the Dialectica, within his

1 A. Louth, St. John Damascene: Tradition and Originality in Byzantine Theology, Oxford, 2002, p. 42; S. Žunjić, "John Damascene's "Dialectica" as a Bond between Philosophical Tradition and Theology," in: The Ways of Byzantine Philosophy, ed. Mikonja Knežević, California, 2015, pp. $227-270$, here 242.

2 See M. Roueché, "A Middle Byzantine Handbook of Logic Terminology," Jöв, 29 (1980), pp. 71-98; M. Roueché, "Byzantine Philosophical Texts of the Seventh Century," Jöв, 29 (1974), pp. 61-76; Louth, St. John Damascene: Tradition and Originality, p. 41.

Demetracopoulos, on the other hand, suggests that it is not improbable that John Damascene had full access to the works of the Aristotelian commentator Stephanus and through him also to Ammonius. (J. A. Demetracopoulos, "In Search of the Pagan and Christian Sources of John of Damascus' Theodicy. Ammonius, the Son of Hermeias, Stephanus of Athens and John Chrysostom on God's Foreknowledge and Predestination and Man's Freewill," in: Byzantine Theology and its Philosophical Background, ed. A. Rigo. (Studies in Byzantine History and Civilization, 4), Turnhout, 2011, pp. 50-86, here 65, 69.) 
theological works. ${ }^{3}$ It is of course known that some of John's philosophic concepts also derive from patristic sources. ${ }^{4}$

Recent studies, however, have redirected scholarly attention to the importance of John's philosophical works and their potential influence on his theological argumentation. According to V. Kontouma and S. Ables, before the compilation of his philosophical works, John's theology was based primarily on Scripture and the Fathers, but afterwards, philosophical speculation starts to be involved, as well. ${ }^{5}$ In other words, the process of composing philosophical writings initiated a shift in John's approach to theology, inspiring him to make more use of philosophy, which was obviously beneficial in battling antiChalcedonian understandings, especially Monothelitism and Monoenergism. ${ }^{6}$

3 Richter has pointed out that the textual logic of the Philosophical Chapters seems to have not been used in any of John's other works, nor does it have any relevance to John's theology in general (G. Richter, Johannes von Damaskos, Philosophische Kapitel (Bibliothek der Griechischen Literatur, 15), Stuttgart, 1982, p. 82); A. Louth generally accepts Richter's observation that the Dialectica is not extensively used in John's other works, but points out that it would be incorrect to say that the Dialectica has nothing to do with John's other works. According to Louth, John compiled the Dialectica for novice students of theology in order to train them to think and argue convincingly (Louth, St. John Damascene: Tradition and Originality, p. 46); K. Oehler also brings up the fact that many terms in the Dialectica are seldom used in John's theological treatises, which makes it unlikely that it was used as a general philosophical introduction to John's theological works. According to Oehler, the only terms in the Dialectica present in John's theological works are those also used by the Fathers. This observation leads Oehler to presume that the main aim of the Dialectica was to help distinguish the Aristotelian use of a term from that of the Fathers (K. Oehler, "Aristotle in Byzantium," Greek, Roman and Byzantine Studies, 5 (1964), pp. 133-146, here 144).

4 M. Trizio, "Reading and commenting on Aristotle," in: The Cambridge Intellectual History of Byzantium, ed. A. Kaldellis, N. Siniossoglou, Cambridge, 2017, pp. 397-413, here 398; G. Zografidis, "Aristotle and John of Damascus: The "first unmoved mover" and "GodCreator", in: Aristotle on Metaphysics, Thessaloniki, 1999, pp. 201-221, here 206, 208; Žunjić. “John Damascene's “Dialectica”, pp. 235-237. For patristic sources, John probably used different patristic collections and floregia (Louth, St. John Damascene: Tradition and Originality, pp. 31-37).

5 S. Ables, "Development in Theological Method and Argument in John of Damascus," JEcs, 21 (Spring 2021), pp. 11, 16 (early final manuscript); V. Kontouma, John of Damascus: New Studies on His Life and Works, Burlington, 2015, I, pp. 38-39.

6 According to M. Roueché, the logical compendia and handbooks, of which the Dialectica is a late example, largely possessed an anti-Monothelite character. (M. Roueché, "Byzantine Philosophical Texts of the Seventh Century," p. 64). In a similar way, both the Institutio Elementaris (IE) and the Dialectica are written to present more powerful arguments against the non-Chalcedonians (Monophysites and Monothelites). See Louth, St. John Damascene: Tradition and Originality, pp. 39-40; V. Kontouma, "Jean Damascène: l'homme et son œuvre dogmatique," Connaissence des Peres de l'Eglise, n. 118 (2010), p. 10; V. Conticello, "Recherches sur la dogmatique orthodoxe : le principe «philosophia ancilla theologiae» et le plan de la Source de Connaissance de Jean Damascène," in: École pratique des hautes études, Section des sciences religieuses, Annuaire, 110, 2001-2002, pp. 367-37o, here 369. 
This of course raises the question of how exactly this philosophical inspiration took place and, most significantly, how original and creative was John Damascene in its implementation. ${ }^{7}$

In order to attain a clearer picture of how this might have occurred, I shall turn to John's treatise On the Two Wills and Energies of Christ (Volunt.). The first reason for this selection is the fact that it is one of the first theological works written just after the $I E$ and the Dialectica brev., and should therefore work as a first example of this philosophical watershed. ${ }^{8}$ And the second reason is that the Volunt. contains a philosophical concept in itself unrelated to Christianity: the list of the Aristotelian types of motion. ${ }^{9}$

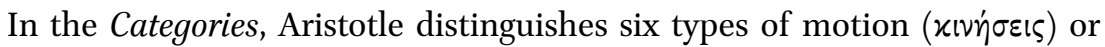

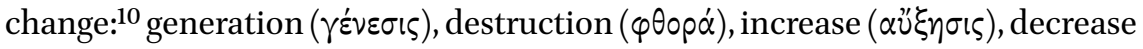

7 The originality or unoriginality of John Damascene is a subject that has been for a long time under intense discussion. John Damascene, in the introduction to the Dial., himself states that he shall say or add nothing of his own, but will only gather what great teachers before him have said. (John Damascene, Dialectica (recensio fusior), prooemium 1: 6o-63, ed. B. Kotter, Die Schriften des Johannes von Damaskos, 1 (PTS, 7), Berlin, 1969, p. 53). Many have considered this statement to indicate nothing more than John's humility; others, on the other hand, consider it to express simple reality. V. Kontouma, S. Ables and D. Bathrellos, amongst many, have tried to show that John Damascene is not merely an unoriginal compiler, but rather a creative thinker. (V. Conticello, "Pseudo-Cyril's De SS. Trinitate: A Compilation of Joseph the Philosopher," ocP, 61 (1995), pp. 117-129; S. Ables, "Did John of Damascus Modify His Sources in the Expositio fidei?," $S P$, LXVIII (2013), pp. 355-361; S. Ables, "Genus and Species," in: The Ways of Byzantine Philosophy, ed. Mikonja Knežević, California, 2015, pp. 271-287; D. Bathrellos, "Saint John of Damascus and the Future of Orthodox Theology," in: Saint John the Damascene, Theology, Image and Melody (Balamand Theological Conference 3), P. Georgi (ed), Amchit-Lebanon, 2012, pp. 203-223, here 212-215.). John Demetracopoulos, on the other hand, is critical of such positivistic approaches and claims that the understanding of John Damascene as an unoriginal compiler should not be so easily abandoned. According to Demetracopoulos, in many cases John lacks even verbal originality, and most of his writings constitute more a "mosaic of quotations" than original pieces. (Demetracopoulos, "In Search of the Pagan and Christian Sources of John of Damascus' Theodicy." pp. 50-86, here 50-55, 81-85.).

8 S. Ables dates the Volunt. (c. $705 \mathrm{AD}$ ) early after John's philosophical watershed, that is, just after the composition of $I E$ and Dial brev. (S. Ables. "Development in Theological Method," pp. 12, 16-17.

9 John Damascene, De duabus in Christo voluntatibus 18:16-19, ed. B. Kotter, Die Schriften des Johannes von Damaskos, 4 (PTS, 22), Berlin, 1981, p. 200.

10 According to Aristotle's Physics, generation and destruction are changes, but not motions, whereas in his Categories such a distinction is not made, which means that generation and destruction are also seen as motions. According to the Categories, all changes are necessarily motions and all motions changes. (Aristotle, Categories, 14, 15a13-15b16; Aristotle, Physics, 5.1, 225a21-35. See also W. K. C. Guthrie, A History of Greek Philosophy: Aristotle an Encounter, vI, Cambridge, 1981, p. 120 n. 2.; I. Bodnar, "Aristotle's Natural Philosophy," in: The Stanford Encyclopedia of Philosophy, Spring 2018 Edition, pdf version, p. 29 n. 11. 


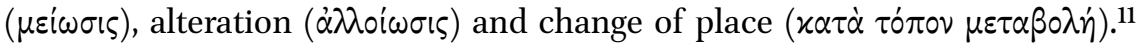
According to Aristotle, genuine change can only occur in these six ways. ${ }^{12}$

The concept of different types of motion remains an important element in the subsequent Aristotelian commentary tradition of the Neoplatonic Alexandrian school, where it circulates up until the sixth century..$^{13}$ By the time, however, that the commentary tradition of the Alexandrian school was replaced by Christian handbooks of logic, no trace of the Aristotelian types of motion remained. ${ }^{14}$ Significantly, to the best of my knowledge, none of the currently known Christian logical compendia that predate John Damascene preserves the tradition of the list of the Aristotelian types of motion. ${ }^{15}$ The first handbook of logic known to refer to this tradition is the philosophical Dialectica of John Damascene, specifically its chapters 62 and $68 .{ }^{16}$ But the most

11 Arist. Categories, 14, 15a13-14.

12 See Bodnar "Aristotle's Natural Philosophy," p. 7.

13 The latest references to the Aristotelian types of motion are found in John Philoponus, In Aristotelis categorias commentarium, ed. A. Busse, Philoponi (olim Ammonii) in Aristotelis categorias commentarium (Commentaria in Aristotelem Graeca 13.1.), Berlin, Reimer, 1898, p. 197, 10-11; p. 198, 21-22; Olympiodorus, In Aristotelis categorias commentarium, ed. A. Busse, Olympiodori prolegomena et in categorias commentarium (Commentaria in Aristotelem Graeca 12.1.), Berlin, Reimer, 1902, p. 146, 2-3; and Elias, In Aristotelis categorias commentarium, ed. A. Busse, Eliae in Porphyrii isagogen et Aristotelis categorias commentaria (Commentaria in Aristotelem Graeca 18.1.), Berlin, Reimer, 1900, p. 253, 27. The 7 th century philosopher Stephanus mentions nothing about the list of Aristotelian types of motion.

14 According to Roueché, from the 7 th century onward, philosophical activity was carried on mainly, if not only, on the level on logical compendia and handbooks, which themselves were shorter summarizing extracts of the preceding Alexandrian commentary tradition. (Roueché, "Byzantine Philosophical Texts of the Seventh Century," p. 67); see also R. Sorabji, “The ancient commentators on Aristotle," in: Aristotle Transformed: The Ancient Commentators and their Influence, ed. R. Sorabji, Ithaca - New York, 199o, p. 19.

15 For examples of logical handbooks and collections of definitions, one could look to Ephrem of Antioch and his Epistula ad Acacium philosophum; Anastasius of Antioch and his Capita philosophica (Definitiones); chapters 14, 18 and 23 of the Theological and Polemical Opuscula, later attributed to Maximus the Confessor; Doctrina Patrum; chapter 2 of the Hodegos (Guide or Viae Dux) of Anastasios of Sinai; Proparaskeuê of Theoodore Raithu; M. Roueché has also published some, mainly anonymous, logical handbooks and collections of definitions. (See A. Grillmeier, Christ in Christian Tradition: From the Council of Chalcedon to Gregory the Great, vol. 2, transl. P. Allen and J. Cawte, Atlanta, 1987, pp. 84-85; Roueché, "Byzantine Philosophical Texts of the Seventh Century," pp. 61-76; Roueché, "A Middle Byzantine Handbook of Logic Terminology," pp. 71-98; A. Louth, St. John Damascene: Tradition and Originality, p. 43.) None of the aforementioned handbooks contains a list of the Aristotelian types of motion and change.

16 John Damascene, Dialectica fus. 62 (brev. 45): 9-14, 16-19, pp. 129-130; fus. 68:10-16, pp. 140-141. M. Roueché suggests that John's Dialectica is probably based on one or multiple Christian logical handbooks or compendia that are in large part currently unknown 
peculiar thing is that the Damascene uses the Aristotelian types of motion, in tandem with the intelligible type of motion, also in his theological works: the Voluntatis and the Expositio fidei. ${ }^{17}$ John's decision to do so stands out even more in light of the fact that these same logical concepts appear very rarely in the patristic tradition prior to John. This comparatively vigorous application of the different types of motion in John Damascene's theology begs for some sort of explanation.

To gain insight into this matter, I shall study John's use of the list of the different types of motion in his theological work the Volunt., attempting in the course of this to account for the influence on his work of various sources. The ultimate aim of this paper is to shed light, through an analysis of John's use of the Aristotelian and intelligible types of motion, on the particular way John Damascene implements philosophical logic in his theological argumentation. Although the list of the different types of motion is also present in John's Expositio fidei, I will concentrate mainly on the Volunt., as a thorough analysis of both of them would require more space than a single article provides.

\section{The List of Different Types of Motion in the Volunt.}

On the Two Wills and Energies of Christ (Volunt.) is a Christological work of John of Damascus in which he aims to refute the heresies of the Monothelites and Monoenergites. The application of the Aristotelian types of motion arrives at the point in the text where John presents us with humanity, with its bodily and intelligible functions, ${ }^{18}$ as a microcosm. ${ }^{19}$ In this way, John formulates an anthropological model that he then employs to describe the functions of Christ's human nature.

In the sphere of this psychosomatic anthropological model and its functions, chapter 18 of the Volunt. begins with an explication of which of these

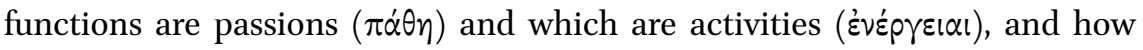

to us. (M. Roueché, "Byzantine Philosophical Texts of the Seventh Century," pp. 66-67;

M. Roueché, "A Middle Byzantine Handbook of Logic Terminology," p. 85.)

17 John Damascene, Volunt. 18:16-17, p. 200; Expositio fidei 3:32-33, ed. B. Kotter, Die Schriften des Johannes von Damaskos, 2 (PTS, 12) Berlin, 1973, p. 11.

18 Volunt. 15-17, pp. 198-200.

19 John Damascene explains that humanity is an entity composed of a rational soul and a mortal body, uniting in itself the sensible and intelligible realities. Humanity may be therefore called mikros kosmos (small world), which means that it unites and represents in it all the intelligible and sensible properties and functions of the macrocosmic created realm. (Volunt. 15:1-17, p. 198.) 
these are related to the human will $(\theta \dot{\varepsilon} \lambda \eta \sigma \varsigma) .{ }^{20}$ In order to clarify the matter, the Volunt. first of all distinguishes between human functions that are activities and those that are irrational passions. ${ }^{21}$ According to John, the criterion of difference between an activity and a passion is that an activity is a movement derived from nature, whereas a passion is a motion resulting from an activity that affects the nature. ${ }^{22}$ In the Volunt., both activities and irrational passions are essentially motions that are related to nature, which means that they are God-given and therefore innocent. ${ }^{23}$

In order to establish this more firmly, chapter 18 of the Volunt. then defines nature as "the law and power given in the beginning by the Creator to every species, according to which it moves or reposes." ${ }^{24}$ This connection becomes possible for John thanks to an element of Aristotelian logic, according to which nature is an inner principle of motion or rest. ${ }^{25}$ The necessity of bringing in this definition of nature makes clear John's aim in dealing with the phenomenon of motion: to provide more solid proof of the naturalness of activities and irrational passions. ${ }^{26}$ Motion as a principle that derives from nature now becomes the centre of John's attention, obliging him to lay out the Aristotelian types of motion:

The motions are generation and destruction and alteration, increase, decrease and locomotion, which is in six ways: forward, back, right, left, upward, downward. ${ }^{27}$

After presenting the Aristotelian types of motion, Volunt. distinctively places alongside another type of motion: the process of willing activity by which the

\footnotetext{
$20 \quad$ Volunt. 18:1-51, pp. 200-202.

21 Ibid. 18:5-11, p. 200.

22 John Damascene, Volunt. 18:10-11, p. 200; cf. Institutio Elementaris (IE), 8:1-3; 9:1-3, ed. B. Kotter, Die Schriften des Johannes von Damaskos, 1 (PTs, 7), Berlin, 1969, pp. 25-26. See also Louth, St. John Damascene: Tradition and Originality, p. 138.

23 Volunt. 6 (col.1, 2):21-24, p. 212; 14:1-4, p. 198; 18:1-3, p. 200.

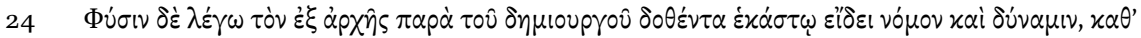

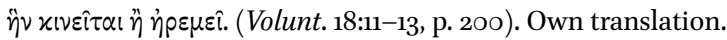

25 Aristotle, Physics, 192b20-23. See also Bodnar, "Aristotle's Natural Philosophy," p. 2 and Zografidis, "Aristotle and John of Damascus," p. 210.

26 For Aristotle, nature and motion see Bodnar, "Aristotle's Natural Philosophy," p. 6.

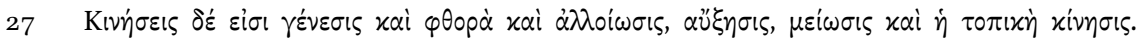

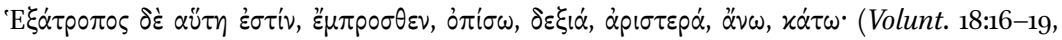
p. 20o. Own translation.)
} 
human mind exercises its free will. ${ }^{28}$ From here through the end of chapter 18, the Volunt. extensively grapples with the concept of human will, asserting that it was given to humanity as a natural endowment in order to control

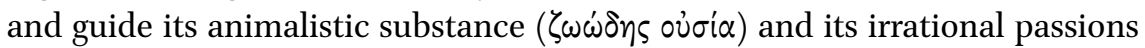
$(\alpha \dot{\lambda} \circ \gamma \alpha \pi \dot{\alpha} \theta \eta) .{ }^{29}$

An eye-catching aspect is that John characterizes this body-mind relation by linking the Aristotelian types of motion to the motion of the willing activity. ${ }^{30}$ John concludes, in a very Aristotelian manner, that the logic of the Aristotelian types of motion is applicable to sensible nature. ${ }^{31}$ Reapplying this logical framework, in Volunt. John makes of the Aristotelian types of motion a tool for elucidating the passive motions ${ }^{32}$ of the sensible and animalistic part of human nature. ${ }^{33}$ In contrast, the Volunt. distinctively emphasizes that the natural motions of the willing process are on the other hand activities. ${ }^{34}$ Sensible

28 Willing activity is here conceived as the thinking and willing process of the human mind:

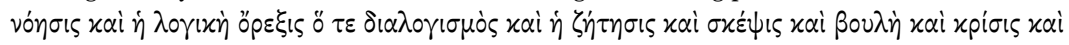

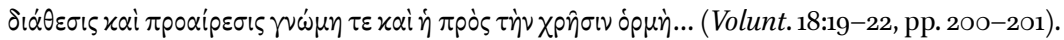
The process of willing activity is also discussed in the 36th chapter of the Exp.. See also Louth, St.John Damascene: Tradition and Originality, pp. 138-139.

29 Volunt. 18:19-51, pp. 200-202.

30 John clearly emphasizes the distinction between Aristotelian types of motion and modes

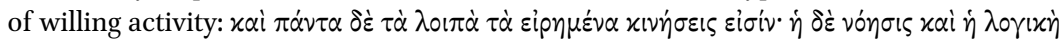

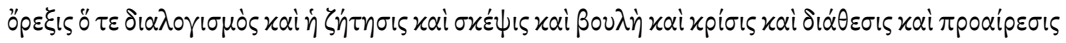

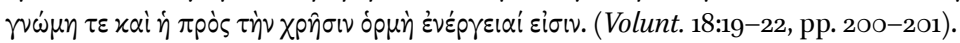

31 Zografidis, "Aristotle and John of Damascus," p. 209.

32 According to John Damascene, the Aristotelian types of motion can be all considered,

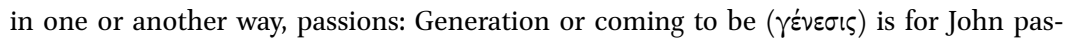
sion (IE 9:4, p. 26). The Volunt. refers to it as a passion of fashioning ( $\left.\delta \iota^{\alpha} \alpha \lambda \alpha \sigma ı \zeta\right)$ (Volunt. 18:9-11, p. 200). For John Damascene fashioning ( $\delta$ í่ $\pi \lambda \alpha \sigma \iota)$ refers to creation or coming to be (John Damascene, Contra Jacobitas 9o:3-5, ed. B. Kotter, Die Schriften des Johannes von Damaskos, 4 (PTS, 22) Berlin, 1981, p. 144; Oration in Sabbatum sanctum 6:7, ed. B. Kotter, Die Schriften des Johannes von Damaskos, 5 (PTs, 29) Berlin - New York, 1988, p. 125). Corruption ( $\varphi$ $\theta 0$ ó) or death ( $\theta \dot{\alpha} \nu \alpha \tau \circ \varsigma$ ) is passion (Volunt. 18:7, p. 200; IE. 9:5, p. 126; Exp. 72:1-3, p. 171). Increase/growth ( $\alpha$ ü $\xi \eta \sigma \varsigma)$ is mainly passion (Volunt. 18:50-51, p. 202), even though it may be also considered to be an activity (IE 8:4, p. 25). Alteration

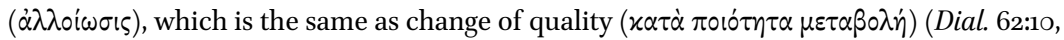
p. 129; Volunt. 18:8, p. 200), is also passion (Volunt. 18:8-9, p. 200). Locomotion (

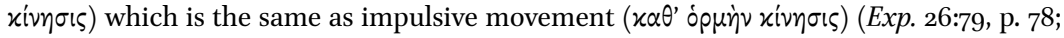
$30: 27-28$, p. 82 ) is passion (Volunt. 18:26-27, p. 201) that may be also an activity (IE 8:4-5, p. 125). That is the reason why the Volunt. calls locomotion as a passive activity or an active passion, as it is a function of the body that is guided by the active will of the soul (Volunt. 18:48-49, p. 202).

33 Volunt. 18:16-37, pp. 200-201.

34 Volunt. 18:19-22, pp. 200-201; cf. IE 8:3,5-11, p. 25. See also Louth, St. John Damascene: Tradition and Originality, p. 171. 
and passive motions are therefore distinguished from the active motions of the rational soul, which has the capacity to freely govern all the natural motions

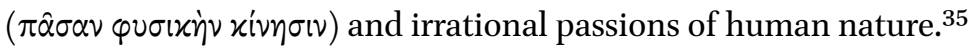

This juxtaposition produces an ingenious microcosmic anthropological model in which the Aristotelian types of motion correspond to the God-given passive functions of the sensible and irrational part of human nature, intended to be guided and governed by the freely willed activity and motion of the intelligible mind. For this very reason, John's theological works (incl. Exp.) never present the Aristotelian types of motion in isolation, but always in tandem with the willing motions of the mind. ${ }^{36}$

As is widely recognized, analogous anthropological models applying to the human being as a unity of body and soul were crafted by non-Chalcedonians as well as Chalcedonians. The non-Chalcedonians argued from such models that just as the soul and body are united in a single composite human nature, in the same way, the united humanity and divinity of Christ should also form a single composite nature and a single composite will and activity. ${ }^{37} \mathrm{John}$, in contrast, concludes from the anthropological model that the incarnated Christ possessed two distinctive natural wills and activities.

The definition of nature with which John works informs his conviction that all motions, both passive and active, derive from nature. In order to determine precisely which motions are inherent to this microcosmic human nature, John lays out all the known types of motion of the created order. The Aristotelian types of motion clearly show which functions belong to the sensible, passive and animalistic part of human nature, and the motions of the willing process indicate which functions belong to the active and intelligible part of the human nature. Christ, being fully human, must evidently have possessed each of these sensible and intelligible functions and motions. If Christ had lacked one of these two types of natural motions, either passive or active, he would

35 Volunt. 18: 19-51, but also IE 8:1-7. See also Zografidis, "Aristotle and John of Damascus," p. 209.

The understanding that sensible and intelligible motions should be distinguished is already seen in John's Against the Manicheans, as well as in his Expositio fidei. (John Damascene, Contra Manichaeos 69:16, ed. B. Kotter, Die Schriften des Johannes von Damaskos, 4 (PTS, 22) Berlin, 1981, p. 388; Exp. 41:1-7, p. 98.)

36 This also becomes evident in the Exp., where the Aristotelian types of motion clearly apply to all sensible reality. Here John refers with it to all the created beings that partake in sensible reality, distinguishing from it the motion via choice of intelligible souls, demons and angels (Exp. 3:27-34). See also Zografidis, "Aristotle and John of Damascus," p. 209.

Louth, St.John Damascene: Tradition and Originality, pp. 139, 167. 
have lacked a fully human nature. ${ }^{38}$ In other words, if Christ indeed possessed a distinct and complete human nature, he must have also possessed a distinct willing activity to govern and guide the motions of the passive and sensible body. Marshalled against non-Chalcedonian viewpoints, John's anthropological model established that Christ's humanity and divinity must necessarily have respectively borne two distinct natural wills and activities. ${ }^{39}$ The logic of the created and natural types of motion therefore helped John to better establish the functions of the created human nature of Christ as distinct from the uncreated divine nature of Christ.

\section{Identifying John's Possible Sources}

Up to this point, we have examined the compilation in the 18th chapter of Volunt. of four essentially separate concepts:

1. activities and irrational passions in relation to nature and motion;

2. the definition of nature as a God-given power of motion;

3. the Aristotelian types of motion as a characterization of sensible and passive nature;

4. the distinctive guiding and governing role of the willing activity of the mind in relation to the sensible and passive part of human nature.

Still unclear, however, are the background and the sources that might have inspired John to pursue this course - an essential component of a comprehensive account of John's implementation of philosophical logic in theology. It appears, as we will see in the following analysis, that John combines lines of argument from multiple sources.

The first extensively used source is naturally John's own Elementary Introduction ( $I E)$, in particular its strongly anti-Monothelite three final chapters (8-10) concerning activities, passions and the will. ${ }^{40}$ The distinction between

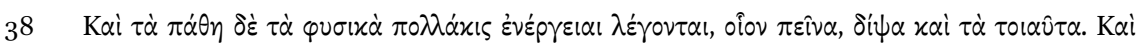

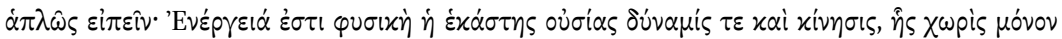

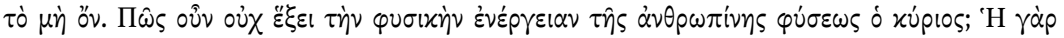

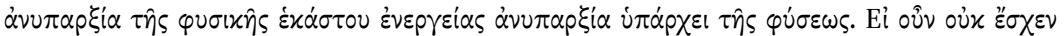

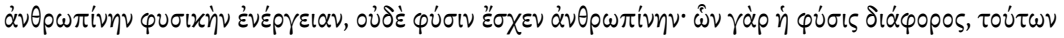

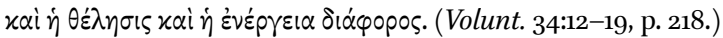

39 Volunt. 28:50-56, p. 212; 34:12-19, p. 218; 39:13-16, p. 225; 40:1-12, p. 225. See also Exp. 59:17-4O, pp. 145-146.

40 Elementary Introduction (Institutio elementaris) is John Damascene's first work of a philosophical kind, preceding the Dialectica; in it he aims to explain the most important terms in light of post-Chalcedonian orthodox teaching. The last three chapters of

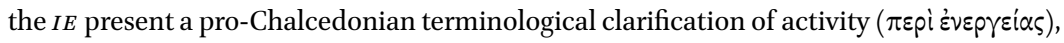


activity and passion found in the Volunt., as well as the different examples of passions and activities and their relation to movement and nature, are more or less also found in chapters 8 and 9 of the $I E .{ }^{41}$ In succession, the influence of chapter 10 of the $I E$ on the Volunt. is apparent in the discussion of the guiding and governing role of the intelligible human will in relation to sensible bodily motions. ${ }^{42}$

Yet at the same time, the $I E$ mentions nothing about the Aristotelian types of motion, neither does John make a move there to link the Aristotelian types of motion with the sensible nature, let alone with the definition of nature itself.

A number of these missing elements are indeed found, however, in John's other philosophical work: the Dialectica. Let us start with the definition of nature as "the law and power given in the beginning by the Creator to every species, according to which it moves or reposes." ${ }^{43}$ Kotter suggests that the Volunt. derives this definition from Elias' Commentary on Aristotle's Categories, ${ }^{44}$ but vast differences between these two textual pericopes exclude the possibility of a direct connection. ${ }^{45}$ The primary point of divergence is that the Volunt. holds nature to be not simply a principle of motion and rest, but a God-given power and principle of motion and rest. ${ }^{46}$ The reference to Creator (God), of course, indicates a Christianized version of the Aristotelian definition of nature, ${ }^{47}$ which was evidently useful for the theological arguments of both the proChalcedonians and the anti-Chalcedonians. One can easily conclude that such definitions also made their way into Christian handbooks of logic, of which the Dialectica is known to be a late example. Taking now the definition of nature of the 18th chapter of the Volunt., it is possible to identify this same definition in the Dial., broken down into two parts: one in chapter 31 of Dialectica (Dial. brev. 11) and the other in chapter 41 (Dial. brev. 24). ${ }^{48}$ It follows that the defini-

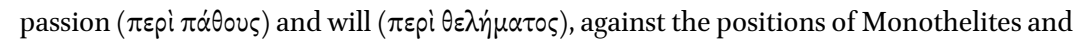
Monoenergites (Louth, St. John Damascene: Tradition and Originality, pp. 39-40). IE 8:1-7, p. 25; 9:1-6, p. 26. See also Louth, St. John Damascene: Tradition and Originality, p. 138 .

42 IE 10:8-22, p. 22.

43 See n. 24.

44 B. Kotter, Die Schriften des Johannes von Damaskos, 4, p. 200.

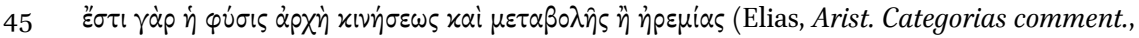
p. 191,8-9).

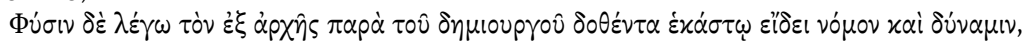

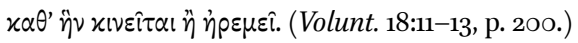

46 Volunt. 18:1-2, 10-16, p. 200.

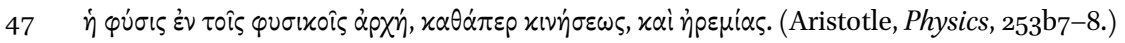

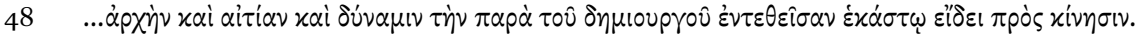

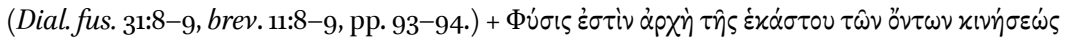


tion of nature in chapter 18 of the Volunt. is John's own creation, an inventive synthesis of components from the Dial..

A highly likely source for the Aristotelian types of motion in the Volunt. is on the other hand the 62nd chapter of the Dial., where the following logic is laid out:49

Dial. I:

In substance, there is generation and destruction; in quantity, there is increase and decrease; in quality, alteration; and in place, motion in a circle, which is called "circular," and motion in straight line, which is called "direct." There are, moreover, six kinds of direct motion: upward, downward, inward, outward, motion to the right, and motion to the left. And so with circular motion there are seven kinds of locomotion. ${ }^{50}$

And slightly further along:

Dial. II:

If this is in the thing itself, it will constitute generation and destruction. If, however, it is in something in the thing itself, this will either be in quantity, in which case it will constitute increase and decrease, or it will be in quality, in which case it will constitute alteration. And if it is in something around the thing, then it will constitute change in place. ${ }^{51}$

As we can see, the 62nd chapter of the Dialectica contains two extended, explicative articulations of the Aristotelian types of motion (Dial. I and Dial. II), whereas the Volunt. presents the types of motion in one version and in a simple list. Even judging only by the general structure of the presentation of

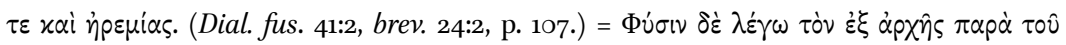

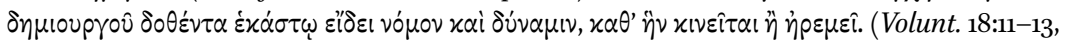
p. 200.)

49 See also B. Kotter, Die Schriften des Johannes von Damaskos, 4, p. 200.

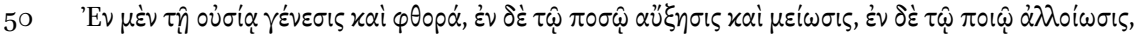

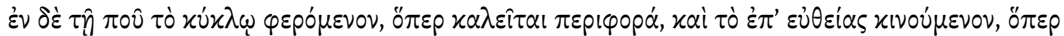

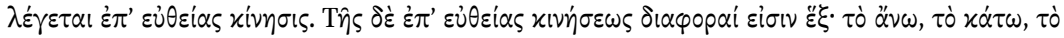

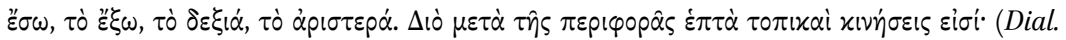
62:9-14, pp. 129-130. Translation with own additions, largely based on F. H. Chase, St John of Damascus: Writings, Fathers of the Church, New York, 1958, p. 94.)

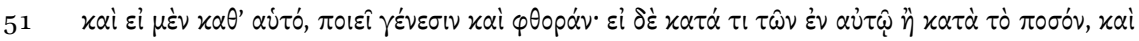

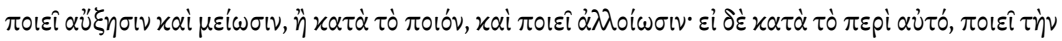

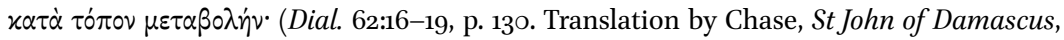
p. 94.) 
Aristotelian types of motion in the two works, a direct link between them should be excluded. Firstly, the 62nd chapter of the Dial. presents the Aristotelian types of motion in two versions, and secondly, it explicates them in terms of their corresponding categories (essence, quantity, quality, etc.). The Volunt., on the other hand, does nothing of the kind, presenting us rather with a straightforward list of the Aristotelian types of motion.

But, at the same time, the types of motion are indeed presented with almost identical vocabulary in the Volunt. and the Dial.. Even though the Dial. II uses the term "change of place" ( $\kappa \alpha \tau \dot{\alpha} \tau \dot{0} \pi \circ \nu \mu \varepsilon \tau \alpha \beta \circ \lambda \dot{\eta} v)$, which is highly characteristic of Aristotle and later Aristotelian commentators, ${ }^{52}$ Dial. I refers to the same idea with the term "locomotions" ( tises, in contrast - including the Volunt. - John Damascene discards the term "change of place" ( $\chi \alpha \tau \dot{\alpha} \tau o ́ \pi \circ \nu \mu \varepsilon \tau \alpha \beta \circ \lambda \eta \dot{\eta} v$ ) from the list entirely, preferring to use only, as in Dial. I, the term "locomotion" instead. ${ }^{54}$ In addition, the Dial. I names six types of direct motion, but adds circular motion, for a total of seven types of locomotion. The presentation of the six types of locomotion in Volunt. therefore overlaps very closely with Dial. I.

It is therefore possible that John drew from the Dial. his preferred vocabulary for the list of Aristotelian types of motion, unburdened it of the corresponding categories, and constructed his own shorter version of it in the Volunt.. In one way or another, the 62nd chapter of the Dial. is the closest source, in terms of vocabulary, for the Aristotelian types of motion in the Volunt..

But missing from the Dial. is the presentation of the Aristotelian types of motion in tandem with the willing motion and activity of the mind. As we have just seen, John's Dial. presents the list of the Aristotelian types of motion without reference to the willing motions, as is also the practice of Aristotle and the late Neoplatonic commentators. In contrast, in John's theological works, including the Volunt., the Aristotelian list of motions is considered insufficient for characterizing the entire created order, and is supplemented with motion of an intelligible kind. This additional motion of the free willing process naturally raises the question of whether John was drawing on other authors within the patristic tradition. Intriguingly, as previously mentioned, the Greek patristic tradition prior to John appears largely unconcerned with

$5^{2}$ See Aristotle, Categories 15a13-14; Ammonius, In Aristotelis categorias commentarium, ed. A. Busse, Ammonius in Aristotelis categorias commentarius (Commentaria in Aristotelem Graeca 4.4.) Berlin, Reimer, 1895, p. 83, 8-9; Olympiodorus, Arist. categorias comment., p. 146, 2-3; Philoponus, Arist. categorias comment., p. 197, 10-11; p. 198, 21-22; Elias, In Arist. categorias comment., p. 253, 27, etc.

53 Dial. 62:10-11, p. 129.

54 Volunt. 18:17, p. 200; Exp. 3:33, p. 11. 
the list of the Aristotelian types of motion. To the best of my knowledge, the only Greek Church Father predating John Damascene who presents us the list of the Aristotelian types of motion is St. John Chrysostom in his Homilies on Colossians (In epistulam ad Colossenses). ${ }^{55}$

The reference to types of motion in Chrysostom's homily:

Tell me then, what is the motion of God? For among us, there are seven of them: upward, downward, inward, outward, right, left, circular; or, if not one of these, then increase, decrease, generation, destruction, alteration. But none of them may be applied to God. Maybe it is the motion of the mind? But not even this, God forbid, as the mind may be often moved improperly. ${ }^{56}$

For comparison, John Damascene's list in the Volunt.:

The motions are generation and destruction and alteration; increase, decrease and locomotion - which is in six ways: forward, backward, right, left, upward, downward. And also all the rest that were mentioned are motions. But thought, rational desire, calculation, inquiry, consideration,

55 John Chrysostom, In epistulam ad Colossenses, v, PG 62, 336.

One of the so-called patristic sources in which we can also find listed the Aristotelian types of motion is chapter 2 of the De sancta trinitate, ascribed to Cyril of Alexandria (PG 77, 1121). Even though it was long considered to predate John Damascene, Vassa Kontouma has adequately demonstrated that De trinitate is actually an encyclopedic text composed by Joseph the Philosopher in the beginning of the 14th century. In the $17^{\text {th }}$ century, it was falsely attributed to Cyril of Alexandria (Conticello, "Pseudo-Cyril's De SS," pp. 117-129; V. Kontouma-Conticello, "À l'origine de la dogmatique systématique byzantine: l'Édition précise de la foi orthodoxe de saint Jean Damascène," in: Byzantine Theologians (Quaderni di Nea Rômè 3), A. Rigo, P. Ermilov (éds), Rome, 2009, pp. 3-17.

As Kontouma's understandings have been since then largely accepted by the modern academic community, I shall set aside the De sancta trinitate. (See Louth, St. John Damascene: Tradition and Originality, p. 87; Ables, "Did John of Damascus Modify His Sources in the Expositio fidei?," pp. 355-361, here p. 354; B. Gleede, The Development of

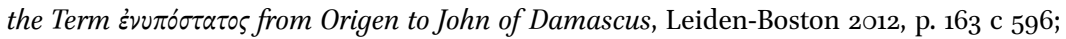
A. C. Echevarria, "Transcendent Exemplarism and Immanent Realism in the Philosophical Work of John of Damaskos," in: Aesthetics and Theurgy in Byzantium, S. Mariev W. M. Stock (ed), Boston-Berlin, 2013, pp. 127-142, here p. 137; Bathrellos, "Saint John of Damascus and the Future of Orthodox Theology," p. 213, c 8.

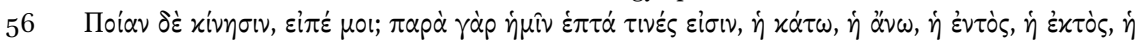

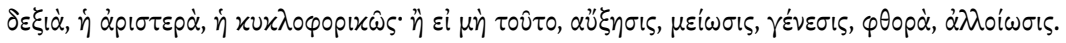

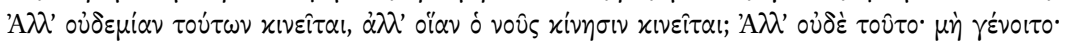

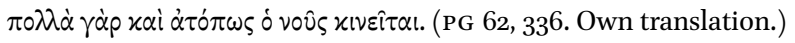


counsel, judgement, disposition, choice, inclination and impulse towards use are activities. ${ }^{57}$

As we can see, Chrysostom begins with seven subtypes of movement, after

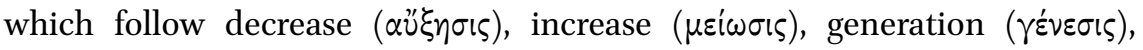
corruption $(\varphi \theta 0 p \dot{\alpha})$ and alteration ( $\left.\dot{\alpha} \lambda \lambda_{0} i \omega \sigma \varsigma \varsigma\right)$. The lists of Aristotelian types of motion in Ad Colossenses and in the Volunt. share a simple textual structure, in contrast to the explicative structure of the Dialectica. The vocabulary

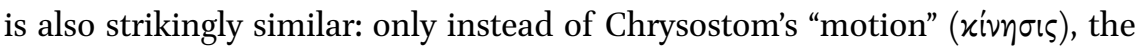

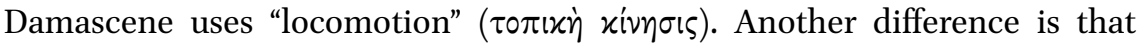
the former names seven types of locomotion, the latter six. In addition, the Ad Colossenses list does not name the Aristotelian types of motion following the classical order, whereas that of the Volunt. does. ${ }^{58}$ As one would expect, the two texts by John Damascene - Volunt. and Dial. - exhibit greater consistency in vocabulary (the use of the term "locomotion") and also in the number of subtypes of direct motion listed (six) with one another than with John Chrysostom's text.

And yet, at the same time, the texts bear a similarity that cannot be overlooked. Perhaps the most striking commonality between the excerpts from Chrysostom's and the Damascene's works is the juxtaposition to the Aristotelian types of motion of the willing active motion of the mind. Chrysostom's motion of the mind is of course presented by the 18th chapter of the Volunt. in a more developed way that details the whole process of the willing activity.

But the question remains, was it in fact Ad Colossenes that inspired John Damascene to deal with the Aristotelian types of motion together with the willing motions of the mind?

A closer look at chapter $\mathrm{v}$ of Ad Colossenes reveals that the Chrysostom lists the different types of motion in order to distinguish types of motion in created reality from the motions of the uncreated God. This thematic combination is strongly paralleled in the anthropological model of the Volunt., which also distinguishes the motions of the created from the uncreated. Also, Chrysostom

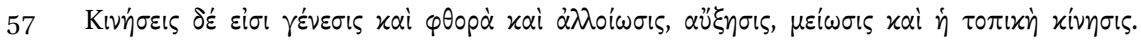

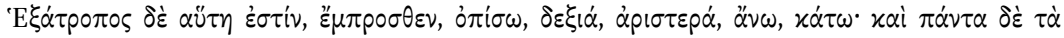

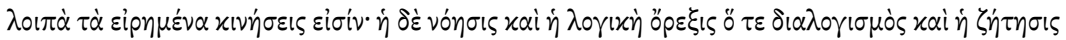

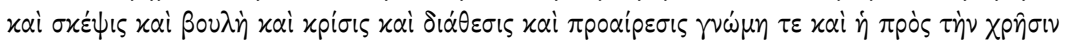

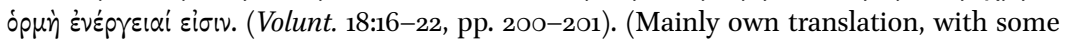
English terminology borrowed from Louth, St.John Damascene: Tradition and Originality, pp. 138-139.)

$5^{8}$ In general, all the lists of the different types of motion from Aristotle onward begin with generation and destruction and finish with locomotion or change of place. 
links the different types of sensible and intelligible motions with the concept of essence (ovं $\sigma^{\prime} \alpha$ ) that is a principle of motion and activity ${ }^{59}$ - a close parallel with the Volunt., in which the different types of passive and active motions are considered to derive from nature. It is reasonable to infer that the Damascene's inspiration for introducing his own version of the definition of nature and linking it with the different types of motion indeed came from Chrysostom. The fact that $\mathrm{Ad}$ Colossenses refers to essence rather than nature does not present a problem, as the Damascene concluded already in his Dial. that the definition of nature is equivalent to the definition of essence. ${ }^{60}$ The potential influence of John Chrysostom becomes evident in the Volunt. and Exp., as well, where the Damascene invokes his authority in arguing for the two natural wills and activities of Christ. ${ }^{61}$ All these similarities, and especially the juxtaposition of the Aristotelian types of motion to the willing motion of the mind, mark Chrysostom's Ad Colossenses as a strongly influential source, the importance of which should certainly not be overlooked.

But at the same time, Ad Colossenses mentions nothing about the process of the willing activity, nor about its governing and guiding capacity, as Chrysostom's main aim is to assert the incomprehensibility of God, not the human nature of Christ.

Here one must turn to the influence of works historically attributed to Maximus the Confessor. The first of such works are the Christological Opuscula theologica et polemica and the Disputatio cum Pyrrho, which seemed to have influenced John to present in detail the process of the willing activity in chapter 18 of the Volunt. ${ }^{62}$ In a similar way to Maximus, John Damascene in chapter 18 of the Volunt. also considers the complicated process of willing activity,

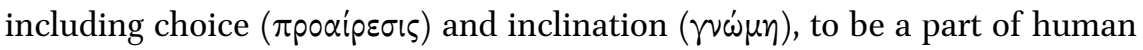
natural will. ${ }^{63}$ As Maximus was known to be the main protagonist in the

59 PG 62, 335-336.

6o Dial. 41:2-10, p. 107 .

61 Volunt. 28:84-88, pp. 213-214. Exp. 59:144-148, p. 149.

62 Maximus the Confessor, Opuscula theologica et polemica, PG 91, 21D-24A; Disputatio cum Pyrrho, PG 91, 293C; see also A. Louth, St.John Damascene: Tradition and Originality, pp. $138,168$.

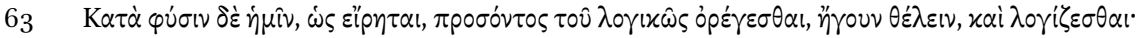

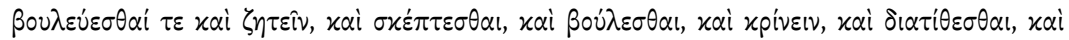

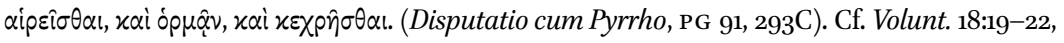
pp. 200-201.

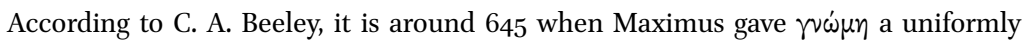
negative meaning and denied that Christ's will is gnomic in any sense. This on the other hand does not mean that according to Maximus Christ's human will lacks the deliberative process of decision-making, Christ simply does not deliberate like the fallen humanity 
polemics against the Monothelites, his influence here is quite to be expected. But, at the same time, Maximus is also known to be influenced by the Aristotelian concept of motion and change. ${ }^{64}$ In the Commentaries on the Divine Names of Dionysios the Areopagite, ${ }^{65}$ Maximus in fact lays out many different types of sensible and intelligible motions, some of which overlap with the known list of the Aristotelian types of motion of the Categories, whereas others do not. ${ }^{66}$ In other words, the Commentary to the Divine Names lacks an orderly list of the Aristotelian types of motion, as presented by the Alexandrian commentators and John Damascene alike. Nor can we find anywhere a case of the Aristotelian types of motion presented together with the process of the willing activity. Even though Maximus' references to the types of motion might have made an impact of a general kind on the Damascene, any direct link between the Commentary to the Divine Names and chapter 18 of the Volunt. should still be excluded.

All of this shows that John Damascene is truly a genius of compilation, who for his chapter 18 of the Volunt. synthesized concepts and patterns from the IE, Dial., Ad Colossenses and from the Christological Opuscula and Disputatio cum Pyrrho, but who in the end transcends the logic of all of those sources and arrives at an original outcome that had not existed before.

The first element of this composite inspirational background is the $I E$, from which John draws the tripartite notions of activity, passion and will - especially

does, plagued by moral ignorance, doubt, and inner conflict that results from being in the grip of sin and passion. (See C. A. Beeley, "Natural and Gnomic Willing in Maximus Confessor's Disputation with Pyrrhus," $S P$, LXXv (2017), Leuven, pp. 167-179).

64 See S. Mitralexis, "Ever-Moving Repose: The Notion of Time in Maximus the Confessor's Philosophy Through the Perspective of a Relational Ontology," PhD dissertation, Freie Universität Berlin, 2014, pp. 125-152.

65 These Scholia were for centuries attributed to Maximus the Confessor, but modern scholarship has proven that comments by both Maximus the Confessor and primarily John of Scythopolis, a bishop of the sixth century, have been merged into a single body of Scholia by the 'Byzantine' copyists of the manuscripts without any note or distinction as to which Scholia belong to whom. Recent scholarship does in no way deny that a significant proportion of these Scholia belong to Maximus the Confessor. However, there is no unequivocal consensus as to which and how many Scholia originated from John of Scythopolis' hand and which from Maximus'. (Mitralexis, "Ever-Moving Repose," p. 35)

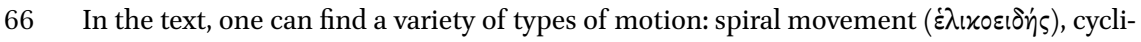

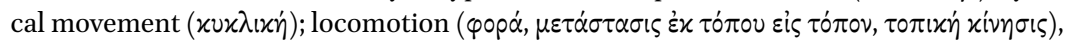

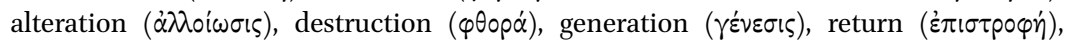

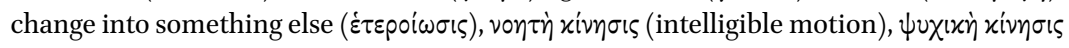
(motion of the soul) and increase ( $\alpha \tilde{v} \xi \eta \sigma \varsigma)$. (Maximus the Confessor, In librum de divinis nominibus scholia, PG 4, 257A-D, 381B-D. See also Mitralexis, "Ever-Moving Repose," p. 139.) There is, on the other hand, no mention of the motion "decrease" ( $\left.\mu \varepsilon^{i} \omega \sigma \iota \varsigma, \varphi \theta i \sigma \iota \varsigma\right)$, nor of the different types of direct motion. 
chapter 10 of the $I E$, which is concerned mainly with how the intelligible will has the power to govern and guide all sensible human reality.

The second element derives from John Chrysostom's Ad Colossenses, from which the Damascene takes the idea of combining essence with motion in its various sensible and intelligible types in order to better distinguish the created from the uncreated. The Damascene clearly appreciated the potential usefulness of this logic in his argument against the Monothelites, as it helped him to distinguish the created human nature of Christ from the uncreated divine nature of Christ. John took up this logic and integrated it with the previously mentioned concepts from the $I E$. In this way, the Aristotelian types of motion are designated as natural passions of the sensible and animalistic part of the human nature, which is governed by the active motion of the mind.

As the precision of definitions is generally a matter of importance for the Damascene, he turns to additional sources for help in giving the existing concept a more detailed form. Chrysostom's concept of essence therefore guided the Damascene to turn to the Dial., which helped him formulate a more exact definition of nature, needed in order to connect all the sensible and intelligible motions with God-given human nature and thereby with the human nature of Christ. Taking Chrysostom's list of types of movement as a starting point, John of Damascus also reshapes this in accord with the representation thereof in the Dial., rendering its structure and wording more applicable to the problem at hand. And lastly, the Maximian works were used to present the simple governing motion of the mind in a more detailed way as a natural process of the willing activity.

This synthesis in the Volunt. results in an impressively original antiMonothelite and anti-Monoenergite implementation of the Aristotelian types of motion, which express the God-given passive and sensible human nature, meant to be guided and governed by the freely willing activity of the mind.

As we have seen from the use of the Aristotelian types of motion in the Volunt., John Damascene proves to be a synthesizer unafraid to employ Aristotelian philosophical logic in his theological argumentation. John does so because he seems to have understood a fundamental Aristotelian logic, according to which from motion one may deduce something about nature and vice versa. But in addition, John appreciated the value of this logic for proving the existence of two distinct natures in Christ along with the functions that go with these natures. This understanding guided John even deeper into the logic of motion 
and thereby into the world of the different kinds and types of motion, which enabled him to argue with greater precision against the non-Chalcedonians.

In so doing, John is clearly drawing both on patristic and Christian philosophical sources, where such ideas already partially existed. Even though the patristic authority of Chrysostom and Maximus would have been sufficient, the Damascene still feels the need to supplement it with concepts from the $I E$ and the Dial. This means that the formulation of these philosophical works indeed formed a watershed, significantly influencing John Damascene and his later theological thinking. The use of the list of the Aristotelian types of motion in one of his philosophic works, combined with the addition of the intelligible motion in two of his theological works, as well, is one clear example of this impact.

But the most striking feature of this innovation is not the extraction of traces of Aristotelian logic from patristic sources in combination with his own philosophical works, but the way this combination takes place. John does not merely compile random concepts from previous patristic and Christian philosophic traditions, but creatively synthesizes them in new contexts with his own personal touch. This means that rather than a mere copyist, John is here more like a creative artist of compilation who mixes different pre-existing colors in order to create new tones. This innovative approach enables John to utilize older logical concepts from the Christian philosophical and patristic tradition, synthesizing them in an original way to meet the Christological challenges of his own era. 